\begin{tabular}{|l|l|}
\hline Postprint Version & 1.0 \\
\hline Journal website & $\underline{\text { www.tsg.bsl.nl/ }}$ \\
\hline Pubmed link & \\
\hline DOI &
\end{tabular}

This is a NIVEL certified Post Print, more info at http://www.nivel.eu

\title{
Hoe te komen tot een populatiegerichte huisartsenzorg?
}

\author{
L.E. MeUWISSEN* , A.J.J. VOORHAM*** , G.M. SCHOUTEN*** , D.H. DE BAKKER* \\ * Ten tijde van het onderzoek: NIVEL, Utrecht \\ ** Hulpverleningsdienst Gelderland Midden (GGD) \\ *** Gemeentelijke Gezondheidsdienst Rotterdam-Rijnmond \\ **** Lectoraat Eerstelijnszorg Hogeschool Rotterdam.

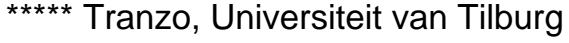 \\ Dr. Liesbeth Meuwissen, Krozengaarde 29, 3992 JP Houten, e-mail: liesbethmeuwissen@yahoo.com
}

Inleiding: Huisartsenzorg heeft in potentie de mogelijkheid om de zorg aan te passen en te richten op de specifieke gezondheidssituatie van de ingeschreven populatie. Tot nu toe is er geen methode ontwikkeld om dit te doen. Tijdens de pilot benchmarking huisartsenzorg in Rotterdam is een methode ontwikkeld om huisartsen te stimuleren tot populatiegerichte zorg en hen hiervoor handvaten te geven. Methode: Huisartsen vulden een internetenquête in over hun zorgaanbod. De gegevens over gezondheidstoestand en risicofactoren uit de GGDGezondheidsenquêtes zijn geselecteerd en berekend voor het verzorgingsgebied van de huisarts. Zo ontstond een praktijkspecifiek gezondheidsprofiel waarmee het zorgaanbod heroverwogen kon worden. Resultaten: Zeventien huisartspraktijken participeerden in deze studie. De praktijken kregen een praktijkspecifiek feedbackrapport waarmee hun zorgaanbod en gezondheidsprofiel werd vergeleken met de feedbackgroep en met Rotterdam. Er is een aanzienlijke variatie in gezondheid en risicofactoren met statistisch significante verschillen tussen verzorgingsgebieden. De huisartsen zijn in vier feedbackgroepen bijeengekomen om de resultaten te bespreken. Deze discussies gingen over de mogelijkheden voor specifieke interventies ter preventie of vroegtijdige opsporing en over mogelijkheden van samenwerkingsrelaties met organisaties gericht op gedragsverandering. Conclusie: De methode bleek een krachtige strategie om huisartsen te stimuleren een meer populatiegerichte benadering te overwegen. Deze relatief simpele aanpak levert een bruikbaar instrument op om een brug te slaan tussen de publieke en de curatieve gezondheidszorg.

\section{INLEIDING}

Populatiegerichte of wijkgerichte eerstelijnsgezondheidszorg is van belang, niet alleen in de zogenaamde Vogelaarwijken (of krachtwijken). Het beter afstemmen van de zorg op de locale omgeving is een belangrijke doelstelling van het beleid, ${ }^{1,2}$ en het idee om wijk- en buurtgericht te gaan werken heeft draagvlak onder de beroepsgroepen. ${ }^{3}$ Door zijn kleinschalige organisatie is de huisartsenzorg zeer geschikt om zich te richten op de specifieke locale situatie. De huisartsenzorg bevindt zich ook in een goede positie om de verbinding tussen preventieve en curatieve zorg te leggen, een andere belangrijke beleidsambitie. ${ }^{4}$ Tot nu toe is er echter geen methode ontwikkeld om tot een populatiegericht zorgaanbod te komen. Het enige dat er is, is de VAAM, de Vraag Aanbod Analyse Monitor, waarbij de locale zorgvraag wordt geschat op basis van landelijke gegevens over zorggebruik(noot a). ${ }^{5}$ 
De huisarts beschikt niet over informatie over de gezondheidstoestand van zijn praktijkpopulatie. Toch wordt deze informatie wel verzameld. In de Wet Publieke Gezondheid (WPG) wordt gemeenten voorgeschreven om op basis van epidemiologische analyse inzicht te verwerven in de gezondheidssituatie van de bevolking. De GGD-en verrichten daarom met enige regelmaat bevolkingsonderzoeken onder de hele Nederlandse bevolking en presenteren deze informatie in rapporten, waarbij wijk, stad (gemeente) en regio niveau onderscheiden worden. Huisartsen kennen deze rapporten meestal niet, en bovendien is het verzorgingsgebied van de huisarts niet aan de wijkgrenzen gebonden. Als deze gegevens beter toegankelijk zijn voor huisartsen, krijgen zij inzicht in de noden van de mensen in hun verzorgingsgebied en kunnen zij evalueren in hoeverre hun zorgaanbod hierop aansluit.

Tijdens de benchmark huisartsenzorg in 2006-2007 is informatie verzameld over het zorgaanbod en heeft het NIVEL samen met de GGD Rotterdam Rijnmond een methode ontwikkeld om de informatie uit de GGD gezondheidsenquêtes terug te koppelen naar specifieke huisartspraktijken. Het doel was om de inzichten opgedaan in de publieke gezondheidszorg toegankelijk en bruikbaar te maken voor de huisarts en zo huisartsen te stimuleren tot nadenken over een meer wijkgerichte benadering. ${ }^{6}$

De vraagstelling die we willen beantwoorden is of er betekenisvolle verschillen zijn tussen verzorgingsgebieden van huisartspraktijken, in hoeverre deze informatie relevant is voor huisartsen, hoe het zorgaanbod gespiegeld kan worden aan het gezondheidsprofiel en of huisartsen denken deze informatie te kunnen gebruiken om hun zorgaanbod aan te passen.

\section{METHODE}

\section{Context}

Rotterdam was één van de vier regio’s waarin in 2006-2007 de pilot Benchmarking Huisartsenzorg plaatsvond. Voor deze pilot was een projectgroep gevormd van vertegenwoordigers van de Huisartsenkring, patiëntenorganisatie RPCP Rijnmond, Zorgverzekeraar Zilveren Kruis Achmea, GGD Rotterdam-Rijnmond en het Ministerie van VWS. Zij werden ondersteund door het Rotterdams Adviesbureau STOEL en door Zorgimpuls, de regionale ondersteuningsstructuur. ${ }^{7}$ Het NIVEL was bij het project betrokken voor de dataverzameling, de datacontrole, analyse en rapportage. Tijdens deze pilot is informatie verzameld uit verschillende bronnen. Dit artikel beschrijft het gebruik van de informatie verkregen uit de GGD gezondheidsenquête in relatie tot de informatie uit de enquête over de praktijkvoering van de huisarts.

De huisartspraktijken zijn geworven door de Huisartsenkring District Rotterdam in Rotterdam en Nieuwerkerk aan de IJssel. Deze praktijken zijn ingedeeld in feedbackgroepen van vergelijkbare praktijken, waarin de uitkomsten aan het eind van de pilot besproken zijn.

Huisartsen kregen allen een enquête voorgelegd over hun zorgaanbod, de zogenoemde

'zorgaanbodenquête'. Zij konden deze enquête op Internet invullen. Deze bestond uit 131 vragen over de patiëntenpopulatie, zorgverleners werkzaam binnen de praktijk, objectieve en subjectieve werkbelasting, toegankelijkheid, bereikbaarheid, preventie (zoals het functioneren van het oproepsysteem voor griepvaccinatie, uitstrijkjes, Astma/COPD), medisch handelen (zoals voorschriften en het risicomanagement hart- en vaatziekten), samenwerking, doelmatigheid en innovatie. De indicatoren waren vastgesteld door de projectgroep en zijn grotendeels afkomstig uit de vragenlijst van de NHG Praktijk Accreditering. Iedere praktijk ontving aan het eind van de pilot een praktijkspecifiek feedbackrapport. In dit feedbackrapport stond het overzicht van de eigen antwoorden, het gemiddelde van de praktijken uit de feedbackgroep en het gemiddelde van alle deelnemende praktijken.

De gegevens over gezondheid en risicofactoren zijn gehaald uit de GGD gezondheidsenquêtes uitgevoerd in 2005, die een breed terrein omvatten van leefomstandigheden, leefgewoonten zorggebruik en -behoeften. De Huisartsenkring Rotterdam heeft uit deze informatie een aantal indicatoren geselecteerd die zij relevant vond voor de vraag naar huisartsenzorg. Dit betrof informatie over de zelfgerapporteerde gezondheidstoestand (de ervaren lichamelijke en psychische gezondheid), de tien meest gerapporteerde ziekten, het alcoholgebruik en roken, en het zorggebruik.

Omdat de huisartspraktijken uit twee GGD regio's komen, zijn gegevens gebruikt van de Rotterdamse gezondheidsenquête onder 15.164 inwoners ${ }^{8}$ en de enquête onder 6.548 inwoners in de regio Gouda. ${ }^{9}$ De respons op de steekproeven in Rotterdam en Gouda was respectievelijk 62\% en 67\%.

In de GGD gezondheidsenquêtes is de psychische gezondheidstoestand nagevraagd middels twee meetinstrumenten: de MHI-5 en K10. De MHI-5, de Mental Health Inventory, is een internationale standaard voor een specifieke meting van de psychische gezondheid bestaande uit vijf vragen. Met de K10 
wordt het risico op depressie bepaald. Dit is een set van tien vragen die betrekking hebben op de maand voorafgaand aan het onderzoek. Voor het meten van het aantal inwoners van Rotterdam met een ziekte en/of aandoening is de respondent gevraagd aan te geven welke van negentien genoemde ziekten of aandoeningen men heeft of de laatste twaalf maanden heeft gehad en of deze wel/niet door een arts zijn vastgesteld. Voor alcoholgebruik is de landelijke standaardvragenset (Lokale en Nationale Monitor Volksgezondheid) gebruikt, bestaande uit vijf vragen. Naast de vraag of de persoon wel of geen alcohol drinkt, werd gevraagd naar de frequentie, wanneer, en het aantal glazen dat er per keer gedronken wordt.

Aangezien er in de enquête niet gevraagd is naar de eigen huisarts, konden de gegevens van de respondenten niet direct aan de huisartspraktijk gekoppeld worden. De gegevens konden wel aan het verzorgingsgebied van de huisartspraktijk gekoppeld worden, aangezien de vier cijfers van de postcode van de respondenten bekend waren uit de gezondheidsenquête. De verdeling van de patiënten over de postcodes binnen de huisartspraktijk was bekend uit het onderzoek naar de patiëntervaring (noot b). ${ }^{10}$

$\mathrm{Er}$ is vervolgens voor iedere indicator een gewogen gemiddelde berekend van de scores uit de gezondheidsenquête in de postcodegebieden waar de patiënten ingeschreven bij de huisarts woonachtig zijn. De betrouwbaarheidsintervallen zijn verkregen met behulp van een gewogen variantieschatting. ${ }^{11}$ In het praktijkspecifieke feedbackrapport stonden de indicatoren uit het verzorgingsgebied van de eigen praktijk (met 95\% betrouwbaarheidsinterval), het gemiddelde van de deelgemeente (waarin de praktijk gevestigd was) en van heel Rotterdam.

\section{RESULTATEN}

Zeventien huisartspraktijken in Rotterdam en Nieuwerkerk aan de IJssel participeerden in deze studie. Deze praktijken waren ingedeeld in 4 feedbackgroepen van vergelijkbare praktijken, die twee keer bijeen gekomen zijn om de uitkomsten te bespreken. Het aantal respondenten op de gezondheidsenquête varieerde per postcodegebied tussen 40 en 163. Gemiddeld genomen waren er 495 respondenten per praktijk. Dit varieerde van 163 tot 1251 respondenten.

\section{Zorgaanbod}

Alle huisartspraktijken hebben het merendeel van de zorgaanbodenquête ingevuld. Echter op diverse onderdelen was de respons matig, zoals bij het voorschrijven van geneesmiddelen $(<50 \%)$ en het aantal patiënten doorverwezen naar specialisten ( $0 \%)$.

Tussen praktijken bestonden aanzienlijke verschillen in aantallen patiënten met verschillende ziekten zoals hart- en vaatziekten en luchtwegklachten (Astma/COPD). Ook bleken er aanzienlijke verschillen in het beleid t.a.v. deze ziekten en hun opsporing. Zo hadden alle praktijken een oproepsysteem voor hypertensie. Voor screening op baarmoederhalskanker had het merendeel een oproepsysteem, maar voor de griepvaccinatie, astma/COPD en risicomanagement hart- en vaatziekten was dit een minderheid. ${ }^{12}$

\section{Gezondheidsprofiel}

\section{Vergelijking van gezondheidsprofielen met deelgemeente en stad Rotterdam}

De gegevens uit de gezondheidsenquête konden worden geleverd voor alle praktijken. De resultaten werden gepresenteerd in een tabel waarvan een voorbeeld voor praktijk x te zien is in tabel 1. De praktijk wordt hierin vergeleken met de deelgemeente en met Rotterdam als geheel.

\section{[TABEL 1]}

In één feedbackgroep bleken de gezondheidsprofielen relatief homogeen en vrijwel identiek aan de deelgemeente. Op andere plaatsen bestonden tussen praktijken die deel uitmaakten van dezelfde deelgemeente aanzienlijke verschillen. Dit geldt bijvoorbeeld voor deelgemeente Kralingen Crooswijk waar significante verschillen bestonden tussen de gezondheidsprofielen van de praktijken voor een groot aantal indicatoren. Op een paar plaatsen bleek dat de gezondheidsprofielen ook sterk konden verschillen voor praktijken die op één adres waren gevestigd (zoals bijvoorbeeld bij een HOED, Huisartsen Onder Een Dak). In de nabespreking bleek dat deze verschillen werden verklaard door een andere spreiding van populaties over postcodegebieden, veroorzaakt door historische gebeurtenissen bijvoorbeeld of een praktijk 'open' of 'gesloten' was op het moment dat een nieuwbouwwijk opgeleverd werd. Het feit dat bij hen 
bekende verschillen tussen praktijken uit de data naar voren kwamen, versterkte voor de huisartsen de waarde van het onderzoek.

\section{Vergelijking van de gezondheidsprofielen onderling}

Er bleken aanzienlijke verschillen te bestaan tussen de gezondheidsprofielen van praktijken onderling. Achtereenvolgens zullen de resultaten gepresenteerd worden van verschillen in lichamelijke en geestelijke gezondheid, verschillen in drie meest voorkomende ziekten en verschillen in risicofactoren.

\section{Ervaren gezondheid}

Er bleken tussen de verschillende praktijken aanzienlijke en statistisch significante verschillen in de ervaren gezondheid tussen praktijken (figuur 1). In de 'gezondste' verzorgde populatie geeft minder dan $10 \%$ van de mensen aan dat hun gezondheid minder dan goed is (8,7\%; 95\% BI 5,5-11,9) en in de 'minst gezonde' geldt dit voor een vierde van de bevolking (25,1\%; 95\% BI 19,4-30,7).

\section{[FIGUUR 1].}

In Rotterdam is een kwart van de bevolking $(24,8 \%)$ licht tot ernstig psychisch ongezond. Er blijken grote en statistisch significante verschillen tussen de verzorgingsgebieden van praktijken. In vier verzorgingsgebieden is meer dan 30\% van de mensen licht tot ernstig psychisch ongezond (95\% BI; 26-38). In zeven andere wijken ligt dit rond de 16\% (95\% BI; 12-20).

\section{Meest voorkomende ziekten}

In Rotterdam heeft bijna de helft van de inwoners (42\%) in de afgelopen twaalf maanden één of meerdere ziekten of aandoeningen gehad. Het gaat hierbij om ziekten en/of aandoeningen die zijn vastgesteld door een arts. De top 11 ziekten in Rotterdam bestond van hoog naar lage frequentie uit: artrose heup/knie, hoge bloeddruk, aandoeningen van de rug, astma/COPD, migraine, nek- en schouderklachten, depressie, diabetes, aandoeningen aan pols en elleboog, chronische gewrichtsontsteking en incontinentie.

Voor drie ziekten wordt de variatie tussen verzorgingsgebieden weergegeven in figuur 2 . In het verzorgingsgebied van praktijk 15 en 17 blijkt het risico op hypertensie significant hoger dan in de andere verzorgingsgebieden met uitzondering van gebied 7 en 14 . Het gaat hier, net als bij astma, om ziekten waarvan de respondent aangeeft dat het door een arts is vastgesteld. Het gemiddelde percentage volwassenen dat in Rotterdam een hoog risico op depressie heeft bedraagt $9 \%$ en dit varieert tussen de verzorgingsgebieden tussen de $2,9 \%$ en de $14,1 \%$.

\section{[FIGUUR 2.]}

\section{Risicofactoren}

Ook in rook- en drinkgedrag zijn aanzienlijke verschillen. Voor Rotterdam als geheel geldt dat gemiddeld $33 \%$ van de mensen ouder dan 16 jaar rookt. Er zijn vijf gebieden waar dit minder dan 25\% is, en 4 gebieden waar dit meer dan $38 \%$ is (figuur 3 ).

\section{[FIGUUR 3.]}

Van de Rotterdamse volwassenen drinkt gemiddeld 14\% excessief of zeer excessief alcohol. Er zijn zeven verzorgingsgebieden waarin dit percentage meer is dan $18 \%$, en twee gebieden waar dit minder is dan $8 \%$.

Daar waar veel gedronken wordt, wordt ook veel gerookt. Maar het is niet zo dat daar waar veel gerookt wordt, ook veel gedronken wordt. In twee van de gebieden (15 en 17) met significant meer rokers, wordt zelfs significant minder gedronken.

\section{Analyse zorgaanbod op basis van gezondheidsprofiel van het verzorgingsgebied van de huisartspraktijk}

Tijdens de nabespreking in de feedbackgroepen bleek dat het merendeel van de artsen erg geïnteresseerd was in de informatie over hun verzorgingsgebied. Bij sommige indicatoren herkenden ze hun praktijk. In een gebied waar significant meer mensen wonen met bijvoorbeeld hart- en vaatziekten herkenden artsen de hoge frequentie van deze problematiek in het spreekuur. De gegevens over de aantallen mensen met 
depressie en mensen met excessief alcoholgebruik was een nieuw soort informatie, die vaak alarmerend werd gevonden.

De verschillen in prevalentie in ziekten en risicofactoren tussen praktijken zwengelden de discussies aan over het aanpassen van het zorgaanbod aan de gezondheidstoestand van de bevolking. Ook werd besproken dat het uitvoeren van gerichte activiteiten voor specifieke groepen patiënten voor praktijken heel verschillende consequenties heeft voor de werkbelasting.

De verschillen tussen verzorgingsgebieden van praktijken in het voorkomen van hoog risico op depressie riepen de vraag op hoe huisartspraktijken hier specifieke aandacht aan zouden kunnen besteden. Een andere vraag was, wat een huisarts kan met het gegeven dat zo'n groot deel van de mensen excessief drinkt. Men vroeg zich af of een arts een even eerlijk antwoord krijgt op een vraag in vergelijking met een anonieme enquête. Ook gingen de discussies over de mogelijkheden om het aanbod aan te passen. Voor een actiever beleid om dit soort problemen op te sporen ontbreekt de tijd. De noodzaak tot het aangaan van samenwerkingsrelaties met andere organisaties die zich specifiek richten op problemen als roken, drinken, depressie en gedragsverandering, werd door velen onderschreven.

In de feedbackgroepen werd eerst het GGD gezondheidsprofiel besproken. Door het vergelijken van de verschillende verzorgingsgebieden kreeg deze informatie betekenis. De relevantie voor de praktijk werd groter toen de informatie besproken werd in relatie tot het eigen zorgaanbod. Er bleek bijvoorbeeld dat in een specifieke praktijk relatief weinig aandacht was voor astma/COPD, terwijl veel mensen in het verzorgingsgebied ermee te kampen hebben. Ook kwam urine incontinentie veel vaker voor dan bij artsen bekend is. Duidelijk werd dat er aan problemen zoals depressie of excessief alcoholgebruik, die in sommige praktijkpopulaties in hoge frequentie voorkomen, relatief weinig aandacht wordt besteed.

\section{DISCUSSIE}

Er bleek een aanzienlijke variatie te zijn in de gezondheidstoestand en de gezondheidsrisico's tussen de populaties uit de verzorgingsgebieden van de huisartspraktijken binnen een relatief klein gebied. Ondanks de relatief kleine steekproeven op postcode niveau, met de bijbehorende grote betrouwbaarheidsintervallen, konden statistisch significante verschillen tussen verzorgingsgebieden worden vastgesteld.

Het merendeel van de huisartsen was zeer geïnteresseerd in de informatie, die nieuwe inzichten gaf in de praktijkpopulatie. De huisartsen hebben diverse mogelijkheden besproken hoe op basis van de nieuwe inzichten het zorgaanbod verbeterd zou kunnen worden. Er is niet geëvalueerd of de nieuwe informatie ook daadwerkelijk invloed heeft gehad op het zorgaanbod.

Er waren aanzienlijke verschillen tussen praktijken in de kwaliteit en de compleetheid waarmee de zorgaanbodenquête was ingevuld. Deze verschillen kwamen voort uit verschillen in de registratiediscipline, in de mogelijkheden van de diverse huisarts informatiesystemen (HIS) en in de handigheid met deze HISsen. De beschikbaarheid van gegevens over het zorgaanbod is essentieel om een analyse te kunnen maken van het zorgaanbod in relatie tot het gezondheidsprofiel, en de huisartsen te ondersteunen in het trekken van consequenties uit het gezondheidsprofiel voor hun praktijkvoering. De verwachting is dat dit soort informatie in de nabije toekomst makkelijker beschikbaar komt, omdat er veel gedaan wordt om belangrijke indicatoren gemakkelijker uit de HIS-sen te kunnen extraheren.

Aangezien de informatie over ziekten en gezondheid op populatieniveau gemeten is, is deze informatie niet één op één geldig voor de mensen ingeschreven in de huisartspraktijk. Echter het gezondheidsprofiel geeft wel informatie over de kans op mensen met bepaalde ziekten of gewoonten in de praktijk. De veronderstelling achter de methode is dat de populatie uit de huisartsenpraktijk een representatieve steekproef is uit de postcodegebieden. Om betere schattingen te kunnen maken, is de aanbeveling om de vraag in welke huisartspraktijk men is ingeschreven in de GGD- enquête op te nemen. Hierdoor is het mogelijk de informatie uit de GGD-enquête direct te koppelen aan de huisartspraktijken.

Een ander punt is dat er bij de gezondheidsenquête in enige mate sprake is van een selectieve respons. Vrouwen respondeerden vaker dan mannen (66\% vs 58\%). Ouderen (55-84) respondeerden vaker dan 1654 jarigen (73\% vs. 56\%). Ook was de respons onder allochtonen lager dan onder autochtonen (39\% tot $53 \%$ versus $70 \%$ ). Uit het non-response onderzoek bleek dat de nonrespondenten de gezondheid als minder goed ervoeren, vaker rookten en minder alcohol dronken dan de deelnemers aan het onderzoek. ${ }^{13}$ Deze selectieve response gold voor alle regio's. Afhankelijk van de samenstelling van de bevolking zal de problematiek in het verzorgingsgebied dus iets over of onderschat kunnen worden. 
Een andere beperking ten aanzien van de gehanteerde methode is dat daar waar de populatie van de huisarts in sterke mate samenvalt met de bestaande wijkgrenzen het gezondheidsprofiel van die specifieke praktijk niet wezenlijk anders is dan de al gerapporteerde GGD cijfers. De meerwaarde zat voor deze praktijken in het gezamenlijk analyseren van de GGD cijfers in relatie tot het eigen zorgaanbod.

Veel huisartsen hadden aanvankelijk moeite met het interpreteren van de GGD gegevens en de relevantie hiervan voor hun praktijk. Het verstrekken van een feedbackrapport bleek niet voldoende. Het nabespreken in feedbackgroepen is belangrijk om grip te krijgen op de data en een relatie te leggen met de eigen praktijk.

Het leggen van de link tussen het gezondheidsprofiel en de eigen praktijkvoering geeft de mogelijkheid om de gegevens uit de praktijk te kunnen interpreteren. Bijvoorbeeld: Kan het lage percentage chronisch zieken in de praktijk verklaard worden doordat de praktijk gelegen is in een wijk met weinig chronisch zieken? Hoe hebben de verschillen in de ziektelast die blijken uit de gezondheidsprofielen weerslag op de problemen die gepresenteerd worden in de huisartspraktijk en op de werkbelasting in de praktijk. Dit onderzoek laat zien dat deze verschillen aanzienlijk kunnen zijn zelfs voor praktijken die dicht bij elkaar gelegen zijn. Verder onderzoek is nodig om te zien of en hoe deze verschillen in praktijkprofiel doorwerken op de diverse prestatie-indicatoren voor de huisartspraktijk.

Daarnaast kunnen de gegevens uit de GGD enquête gebruikt worden om de mogelijkheden voor preventie of gerichte detectie van ziekten of risicofactoren te identificeren. De prevalentie van ziekten en risicofactoren beïnvloedt de effectiviteit en zinvolheid van bepaalde preventieve activiteiten. Inzicht in het praktijkspecifieke gezondheidsprofiel helpt bij het stellen van prioriteiten en ondersteunt zo de ontwikkeling van het zorgaanbod op maat. Dit bespreken van het gezondheidsprofiel hoeft zich niet te beperken tot de huisartspraktijk. Het zou besproken kunnen worden met de bij deze populatie betrokken (eerstelijns)zorgaanbieders om gezamenlijk het zorgaanbod te evalueren en beter af te stemmen op de problematiek die er speelt.

Concluderend, deze relatief eenvoudige methode levert een voor de huisartsen relevant profiel van hun verzorgingsgebied, dat hopelijk navolging zal vinden bij andere GGD-en. De benadering bleek een krachtige strategie om huisartsen te stimuleren meer populatiegericht te denken en hun zorgaanbod te heroverwegen. Met een praktijkspecifiek gezondheidsprofiel krijgen de praktijken handvaten om specifieke aandachtspunten in de reguliere zorg aan te brengen, prioriteiten te bepalen voor preventieve activiteiten, gerichte opsporing of actieve samenwerking met andere organisaties. Het is dan aan de lokale partners om dit concreet vorm te geven. De op de huisartspraktijk toegespitste informatie uit de GGD gezondheidsenquêtes biedt een goede basis om een brug te slaan tussen de publieke en de curatieve gezondheidszorg, en huisartsen te verleiden meer populatiegericht te gaan denken en handelen.

\section{NOTEN}

- Bij de VAAM worden de landelijke cijfers over zorggebruik geëxtrapoleerd naar de locale situatie om de locale zorgvraag te schatten, rekening houdend met de wijkopbouw qua leeftijd, geslacht, etniciteit, stedelijkheid, proportie westerse en niet-westerse allochtoon en proporties huishoudens met een laag inkomen,

- Iedere huisartspraktijk zou deze informatie kunnen aanleveren uit het bestand van de ingeschreven patiënten.

\section{HOW TO MOVE TOWARDS POPULATION BASED PRIMARY CARE?}

Aim: Primary health care potentially offers the opportunity to tailor health service delivery to the needs and demands of the local population. Up to now, there is no clearcut method for doing this. During a pilot benchmark for general practices, an instrument was developed to stimulate General Practitioners (GPs) to consider a more population oriented approach, and to give direction to implement such an approach. Design and Methods: Health service delivery was measured through an internet survey among the GPs. Data on the health status and risk factors were selected from the population-based-survey that had been carried out by the 
municipal health authority. These data were related to the practices' service areas. This provided a practice specific health profile, with which the health care delivery could be reconsidered. Results: Seventeen general practices in Rotterdam, the Netherlands, participated in the study. Practices received a practice specific feedback report. With this report the GPs could compare the services and health care profile of their practice with the feedback group and with Rotterdam. Considerable variation was observed in the health status and health risks between the populations served, with statistically significant differences between the practice service areas. GPs met in four feedback groups to discuss the outcomes. They discussed possibilities for prevention or early detection and the need for collaboration with prevention oriented services. Conclusion: The method proved to be a powerful strategy to stimulate general practitioners to consider a more population oriented approach. The relatively simple approach provides a useful tool to bridge the gap between public and curative health care.

\section{LITERATUUR}

1. Klink A. Visie op de eerstelijnszorg: 'Dynamische eerstelijnszorg'. Kamerstuk, 25 januari 2008. CZ/EKZ/2825209. Den Haag, Ministerie van VWS, 2008.

2. Klink A. 'Doelstellingenbrief eerstelijnszorg'. Kamerstuk, 3 juli 2008. CZ/EKZ/2862066. Den Haag, Ministerie van VWS, 2008.

3. LOVE (landelijk overleg versterking eerste lijn). Programma versterking eerstelijnszorg II. Versie 5.0. Plaats, LOVE, 2008.

4. VWS. Gezond zijn, gezondheid blijven. Een visie op gezondheid en preventie. Den Haag: Ministerie van VWS, 2007.

5. Zwaanswijk M, Quak ES, Bouwman J, Zantinge EM, Verhaak PFM, Bakker DH de. Validiteit van de Vraag Aanbod Analyse Monitor (VAAM): overeenstemming met populatiegegevens uit gezondheidspeilingen. Tijdschr Gezondheidswet 2009; 87:272-8.

6. Voorham AJJ . De toekomst van de eerste lijn in Rotterdam: méér wijkgericht! Openbare les bij de aanvaarding van het lectoraat Eerstelijnszorg bij de Hogeschool Rotterdam. Rotterdam: Hogeschool Rotterdam, 2007.

7. Franchimont M, Pronk J, Tits M van, Reek E van den, Pardoel K. Zichtbaar maken van kwaliteit in de huisartsenzorg. Landelijke evaluatie van vier regionale pilots "Benchmark Huisartsenzorg". Rotteram / Tilburg: STOEL / IVA, 2007.

8. Kuilman, M. Schouten,G. Gezondheidsenquête 2005. Onderzoeksmethodiek en gezondheid in relatie tot achtergrondkenmerken. Een naslagwerk. Rotterdam: GGD Rotterdam-Rijnmond, 2007.

9. GGD Midden-Holland Factsheets 1 Onderzoeksopzet en achtergrondkenmerken. Plaats: GGD Midden-Holland, jaartal.

10. Meuwissen LE, Bakker DH de. CQ -index huisartsenzorg Meetinstrumentontwikkeling. Kwaliteit van de zorg in de huisartsenpraktijk vanuit het perspectief van patiënten. De ontwikkeling van het instrument, de psychometrische eigenschappen en het discriminerend vermogen. Utrecht: NIVEL, 2008.

11. Blalock HM. Social Statistics. New York: Mc Graw-Hill. 1963.

12. Meuwissen LE, Bakker DH de. Rapport Pilot Benchmarking Huisartsenzorg Rotterdam. Utrecht: NIVEL, 2009.

13. Kuilman, M. Schouten, G. Gezondheidsenquête 2005, Onderzoeksmethodiek en gezondheid in relatie tot achtergrondkenmerken. Een naslagwerk. Rotterdam: GGD Rotterdam-Rijnmond, 2007. 
Meuwissen, L.E., Voorham, A.J.J., Schouten, G.M., Bakker, D.H. de. Hoe te komen tot een populatiegerichte huisartsenzorg? TSG: Tijdschrift voor Gezondheidswetenschappen: 2010, 88(7), 381-387

\section{TABEL EN FIGUREN}

Tabel 1 Voorbeeld uit het feedbackrapport van praktijk X

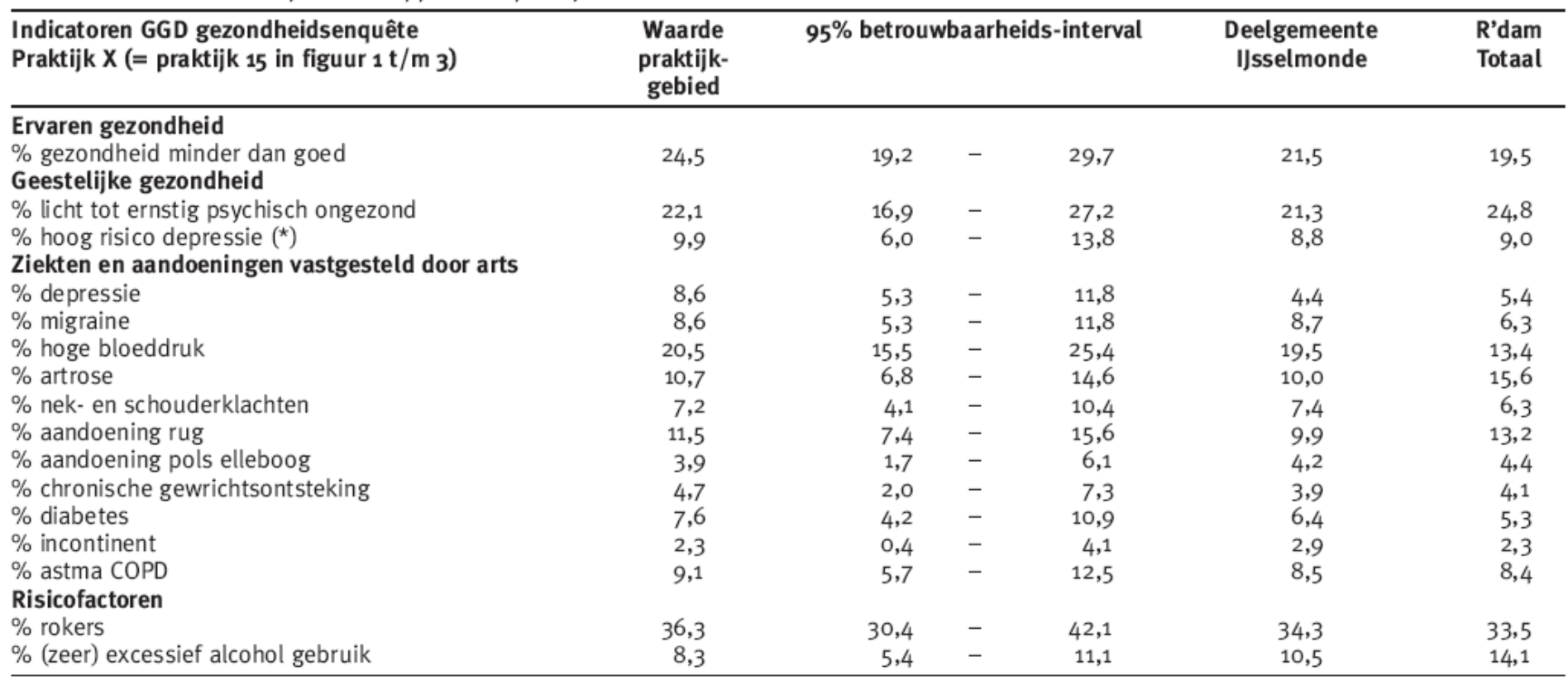

$\left(^{\star}\right)$ risico depressie vastgesteld met een vijfpuntschaal

Figuur 1 Percentages zelfgerapporteerde ervaren gezondheid en psychische gezondheid gemeten met de $\mathrm{MHI}-52$ in de verzorgingsgebieden van de participerende huisartspraktijken

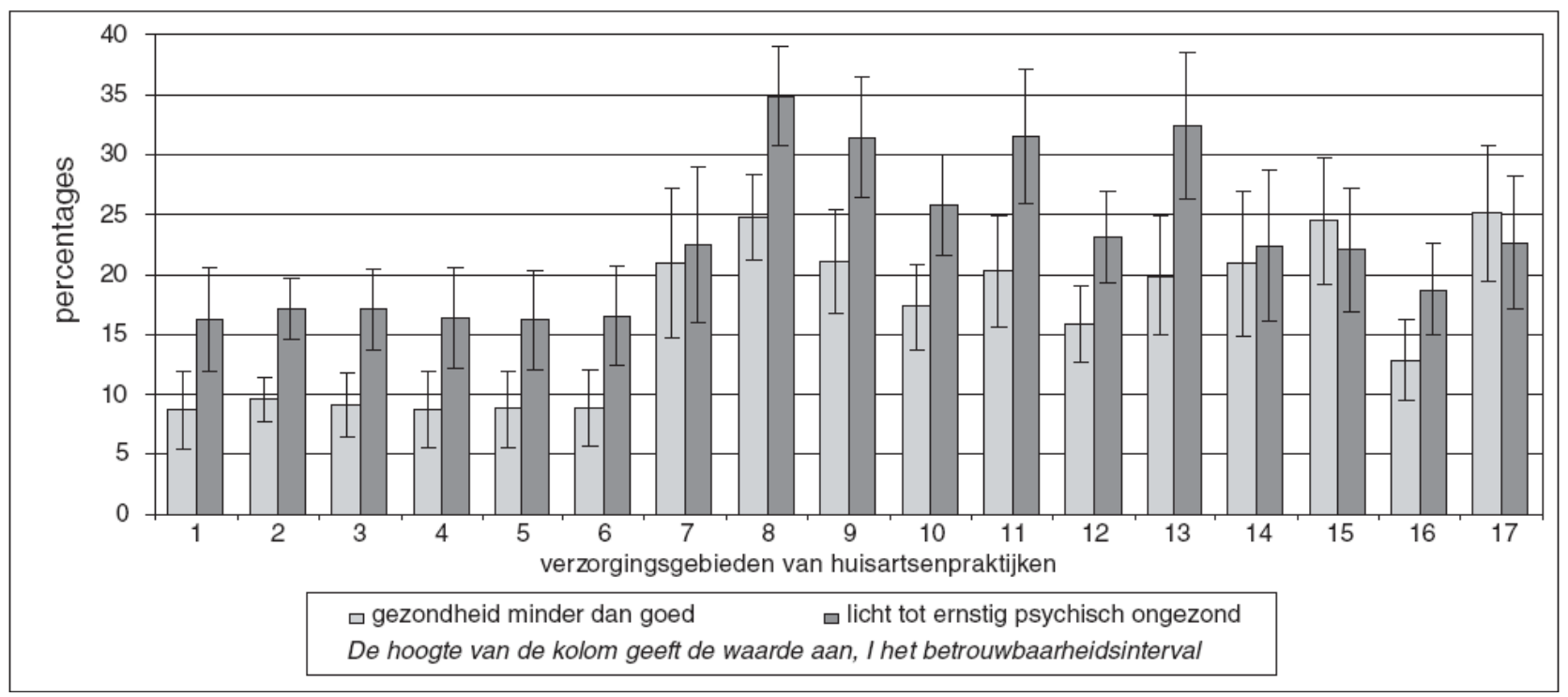


Meuwissen, L.E., Voorham, A.J.J., Schouten, G.M., Bakker, D.H. de. Hoe te komen tot een populatiegerichte huisartsenzorg? TSG: Tijdschrift voor Gezondheidswetenschappen: 2010, 88(7), 381-387

Figuur 2 Prevalentie hypertensie, astma en hoog risico depressie in de verzorgingsgebieden van de participerende huisartspraktijken

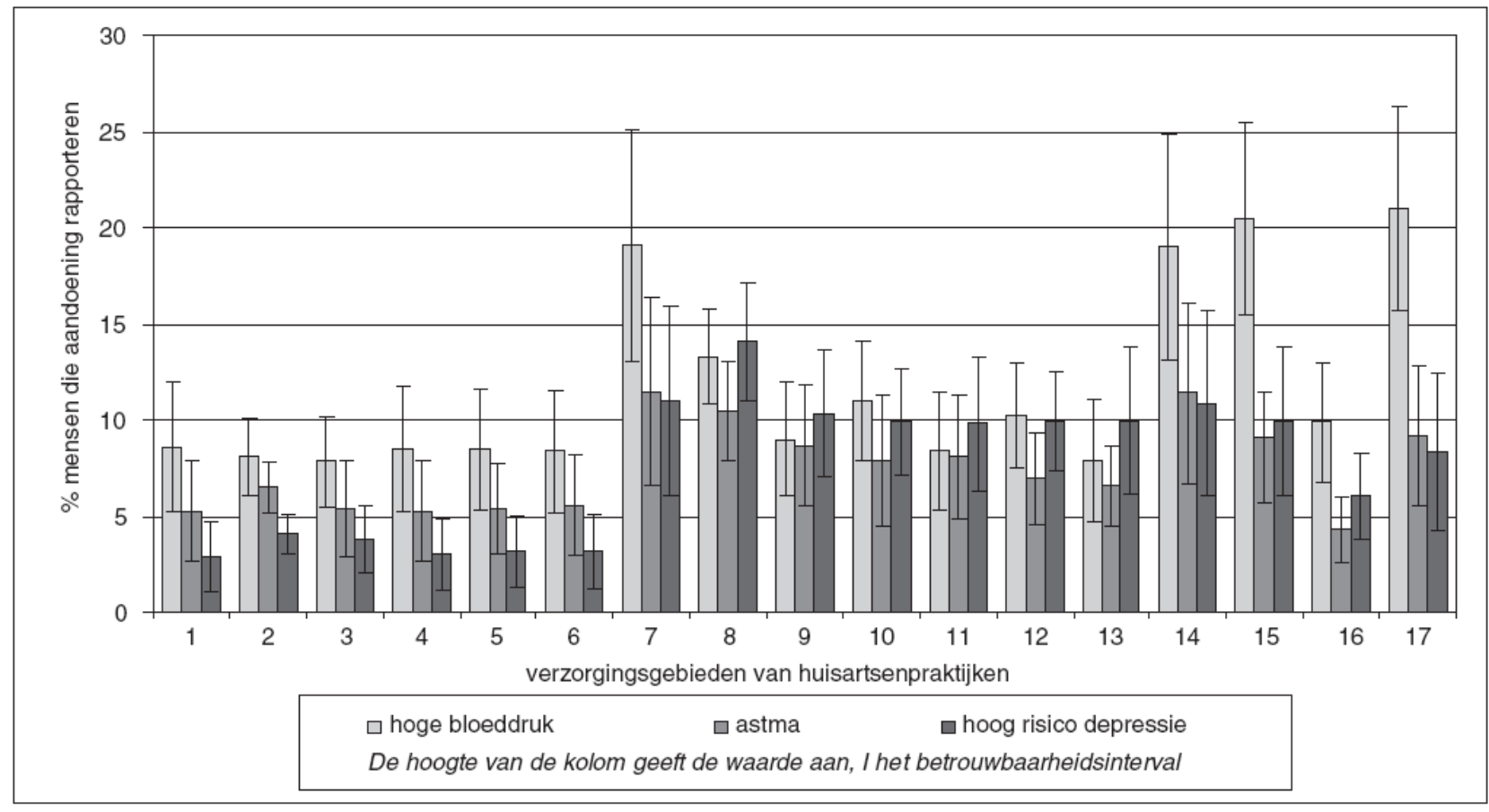

Figuur 3 Percentages rokers en mensen met zeer veel/excessief alcoholgebruik in de verzorgingsgebieden van de participerende huisartspraktijken

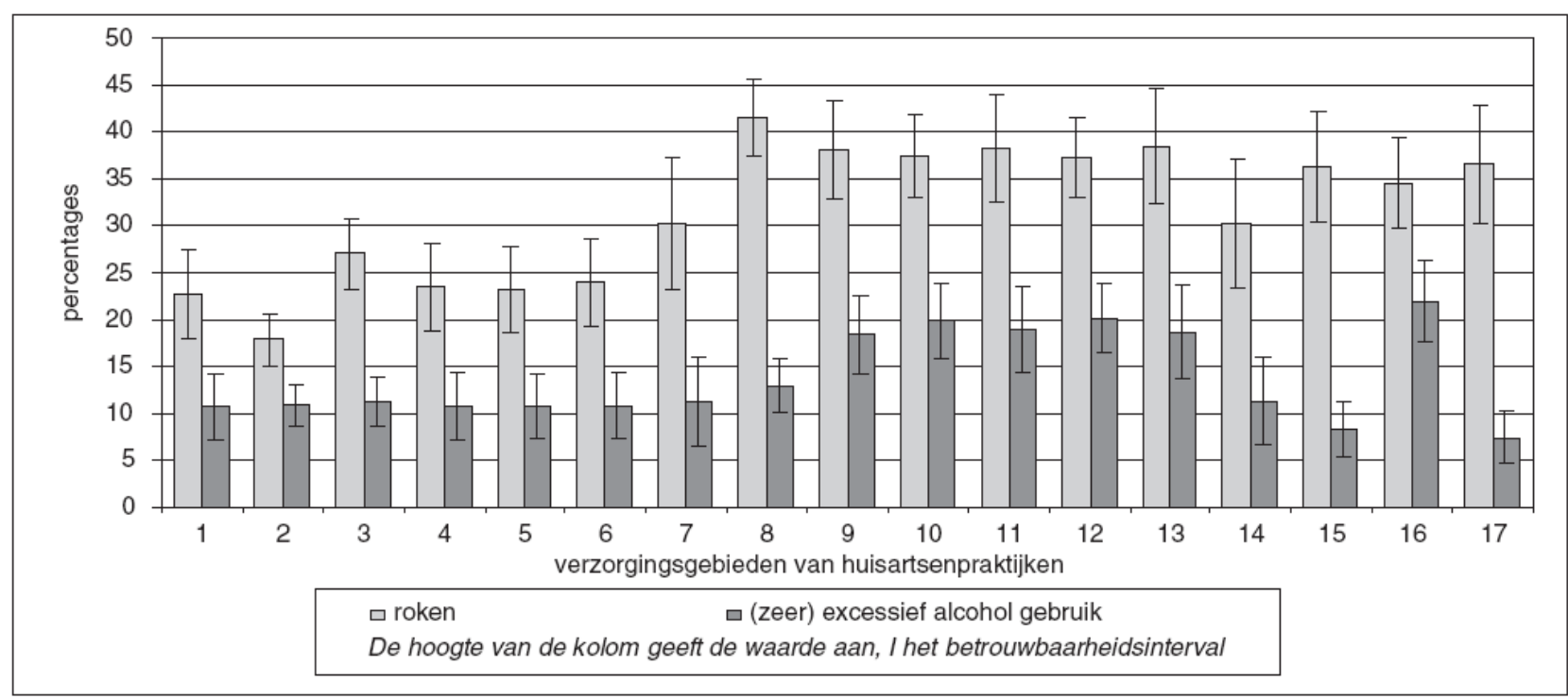

